\title{
イオン交換樹脂を混和したモルタルの 塩化物イオン拡散特性に関する研究
}

\author{
真田 修*1 ・睦好宏史 ${ }^{* 2} \cdot$ 浅本晋吾*3 $・$ 井上喜仁 ${ }^{* 4}$
}

\begin{abstract}
概要: 近年, 塩害地域に位置し, 供用後数十年経過しているコンクリート構造物への補修・補強事例が増える中, 補 修・補強材料としての高性能材料が求められている。一方, 工業用水や純水の製造過程では, 塩化物等の不純物の除 去を目的に従来からイオン交換樹脂が用いられており, その特性は明らかにされている。本論文では, イオン交換樹 脂が持つ塩化物イオンの吸着性能に着目し, 化学的分析によるイオン交換樹脂の塩化物イオン吸着効果の検証, 塩分 浸漬実験による全塩化物量の定量, イオン交換樹脂を混入したモルタルの塩化物イオン拡散に関寸る数值解析, イオ ン交換樹脂による塩化物の除塩特性を検証する実験を行い, イオン交換樹脂を混和したモルタルの塩化物イオン拡散 特性を論じたものである。
\end{abstract}

キーワード : イオン交換樹脂, 塩害, 化学分析, イオン選択性, 浸漬実験, 塩化物イオンの拡散係数, 数值解析

\section{1. はじめに}

近年，塩害地域に位置し，供用後数十年経過した鉄筋 コンクリート構造物の耐久性の低下が懸念される中，合 理性を求めた長寿命化対策 1),2)が行われる等, コンクリ 一下構造物の健全度のより一層の長期間化が求められて いる。一方, 塩害を受けたコンクリート構造物に用いる 補修材として取扱がより安全でコスト面でも優位性のあ る新たな材料が求められている。

本研究は, 従来から, 純水製造等の過程に多用され, 再生可能なイオン交換樹脂（以下, IER）の特性 - 性能 に着目し，これをモルタルあるいは鉄筋コンクリートに 混和させることによる耐塩害特性を論じたものである。

IER は官能基の種類によって, 弱酸性 - 強酸性 ・弱塩 基性・強塩基性に分類される。弱酸性陽 IER - 強酸性陽 IER ・弱塩基性陰 IER の各 IER は, 水中で各々式(1), 式 (2), 式(3)のように解離しイオン交換反応を示す。

$$
\begin{aligned}
& \mathrm{R}-\mathrm{COOH} \rightarrow{\mathrm{R}-\mathrm{COO}^{-}+\mathrm{H}^{+}}^{\mathrm{R}-\mathrm{SO}_{3} \mathrm{H} \rightarrow \mathrm{R}_{-} \mathrm{SO}_{3}{ }^{-}+\mathrm{H}^{+}} \\
& \mathrm{R} \equiv \mathrm{N} \cdot \mathrm{OH} \rightarrow \mathrm{R} \equiv \mathrm{N}^{+}+\mathrm{OH}^{-}
\end{aligned}
$$

モルタルは $\mathrm{pH} 11$ ～13 程度であるため, 使用する IER としては，強塩基性陰 IER（以下，AER）を選定するこ
とが好ましく, AER のイオン交換反応の一例は式(4)で表 される。また, イオン交換反応は可逆反応であるため, 常にイオン交換平衡が成立する。

$$
\mathrm{R}-\mathrm{CH}_{2} \mathrm{~N}\left(\mathrm{CH}_{3}\right) \mathrm{OH}+\mathrm{Cl}^{-}=\mathrm{R}-\mathrm{CH}_{2} \mathrm{~N}\left(\mathrm{CH}_{3}\right) \mathrm{Cl}+\mathrm{OH}^{-}
$$

また，AERによる陰イオン交換には，各陰イオンに対 する選択性の大小があり，この順位は一般的に式(5)のよ うに表される。

$$
\mathrm{SO}_{4}^{2-}>\mathrm{Cl}^{-}>\mathrm{HCO}_{3}^{-}>\mathrm{OH}^{-}
$$

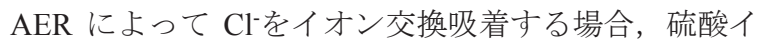
オン（以下， $\mathrm{SO}_{4}^{2-}$ ) が存在する環境下では，より選択性

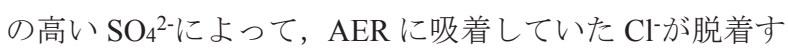
る可能性がある。既往の研究 3)では, AERによって脱塩 効果を高めることが定量的に示されているが，モルタル に含まれる各種陰イオンと AER との交換効率等は明ら かにされていない。

本研究の第一の目的は, モルタル中に存在する塩化物 イオン（以下, $\mathrm{Cl}^{-}$) を AER によってイオン交換吸着す るかどうかを明らかにすることである。本研究の第二の 目的は, AER を混和した硬化モルタルの塩分浸漬実験を 行い, AER の $\mathrm{Cl}^{-}$吸着に及ぼす影響を明らかにすること

*1 埼玉大学 大学院理工学研究科大学院生 工修 (正会員) †105-6011 東京都港区虎ノ門 4-3-1

*2 埼玉大学教授 大学院理工学研究科 工博 (正会員) †338-8570 埼玉県さいたま市桜区下大久保 255

*3 埼玉大学准教授 大学院理工学研究科 工博 (正会員) †338-8570 埼玉県さいたま市桜区下大久保 255

*4 埼玉大学 大学院理工学研究科大学院生 †338-8570 埼玉県さいたま市桜区下大久保 255 
である。さらに，第三の目的は，既に塩化物を含有させ たモルタルへ, AER を混入させた断面修復用モルタルを 貼りつけることにより, 既設塩化物含有モルタル内の $\mathrm{Cl}^{-}$ を断面修復用モルタル側へ移動させる（以下，コンクリ 一ト内部から表面部方向への拡散と呼ぶ）ことによって $\mathrm{Cl}^{-}$を減少させることが可能であるかどうかを明らかに することである。

\section{AERの塩化物イオン吸着効果}

\section{1 化学的分析の概要}

本節では, AER の塩化物イオン吸着効果を化学的な分 析により明らかにすることとした。すなわち, AERがセ

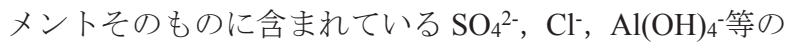
各種陰イオンとどのように交換されるのかを, 下記の(1) および(2)に示す化学的分析により明らかにした。

(1) ポルトランドセメント中の陰イオンの分析

早強ポルトランドセメント（以下， HPC）中に含まれ る各種陰イオンが AER の $\mathrm{Cl}$ 吸着に及ぼす影響を明らか にした。表ー1に HPC の諸元を, 表一2 に AER の仕様を 示す。水と $\mathrm{HPC}$ を $\mathrm{W} / \mathrm{C}=60 \%$ で練混ぜ，約 15 分後にブ リーディング水をろ過することでイオンを溶液中に抽出 した。得られた溶液に含まれる陰イオンをJIS 3813-2003 によるキャピラリー電気泳動法で分析した。また, AER 含有率 $3 \%$ のモルタルを使って, HPC から溶出する陰イ オンの全てが AER に吸着されれば，AER のイオン交換 容量の何\%を占めるのかを試算した。

（2）アルミナセメント中の陰イオンの分析・選択性

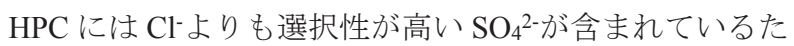

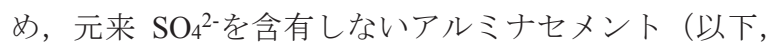
CAC）に着目した。使用した CAC の種別はシマンフォ ンジュ（以下， CAC-C）とターナルホワイト（以下, CAC-T）とし，分析手順は 2.1(1)と同様で，W/C は $60 \%$

表 $-1 \quad H P C$ の諸元

\begin{tabular}{|c|c|c|c|}
\hline \multicolumn{2}{|c|}{ 品質項目 } & 単位 & 試験成績 \\
\hline \multicolumn{2}{|l|}{ 密度 } & $\mathrm{g} / \mathrm{cm}^{3}$ & 3.14 \\
\hline \multicolumn{2}{|c|}{ 比表面積 } & $\mathrm{cm}^{2} / \mathrm{g}$ & 4560 \\
\hline \multirow{3}{*}{ 凝結 } & 水量 & $\%$ & 30.7 \\
\hline & 始発 & h-min & $1-50$ \\
\hline & 終結 & $\mathrm{h}-\mathrm{min}$ & $2-53$ \\
\hline
\end{tabular}

表一2 AER の仕様

\begin{tabular}{|l|l|}
\hline 母体構造 & スチレン系 \\
\hline 分類 & 強塩基性アニオン交換樹脂 \\
\hline 見掛け密度※1 $(\mathrm{g} / \mathrm{L})$ & 約 660 \\
\hline 総交換容量※1 $(\mathrm{eq} / \mathrm{L})$ & 1.25 \\
\hline 有効 $\mathrm{pH}$ 範囲 & $0 \sim 14$ \\
\hline
\end{tabular}

$※ 1 \quad$ L は見掛けの容積
とした。

CACを使用したモルタルには，後述する 2.2(1)で分析 した陰イオンの他に, CAC 由来のアルミニウム（以下， $\mathrm{Al})$ がアルミン酸イオン（以下， $\mathrm{Al}(\mathrm{OH})_{4} 4^{-}$) の形態で一 価の陰イオンとして存在し, AER に吸着する可能性があ るため, $\mathrm{Al}(\mathrm{OH})_{4}^{-}$の $\mathrm{AER} へ の$ 吸着性を確認することとし た。分析手順は，ブリーディング水をろ過するところま では 2.1(1)と同様で, 得られた溶液をカラムに充填した AER に通液する過程において, カラム入口溶液と, カラ ム出口溶液の中に含まれる $\mathrm{Al}(\mathrm{OH})_{4}-$ の定量分析を行った。 カラム入口溶液の $\mathrm{Al}(\mathrm{OH})_{4}^{-}$より, カラム出口溶液の $\mathrm{Al}(\mathrm{OH})_{4}{ }^{-か ゙}$ 少なければ，溶液中の $\mathrm{Al}(\mathrm{OH})_{4}$-成分が $\mathrm{AER}$ に 吸着されたことになる。溶液中の Al は JIS K 0102 による 誘導結合プラズマ発光分光分析（以下，ICP-AES）で分 析した。

$\mathrm{CAC}$ に含まれる $\mathrm{Al}(\mathrm{OH})_{4}^{-}$の選択性が $\mathrm{Cl}^{-}$より大きけれ ば，AER に吸着していた $\mathrm{Cl}^{-}$が $\mathrm{Al}(\mathrm{OH})_{4}$-と入れ替わる可 能性があるため, $\mathrm{Al}(\mathrm{OH})_{4}$ - と $\mathrm{Cl}^{-}$の選択性の優劣を明らか にした。分析手順は，ブリーディング水をろ過するとこ ろまでは2.1(1)と同様で，得られた溶液に，AER を投入 して 16 時間擋拌（以下，擋拌 a) し， AER に $\mathrm{Al}(\mathrm{OH})_{4}^{-}$ を吸着させ，次にその $\mathrm{AER}$ を $\mathrm{NaCl}$ 溶液に投入して 16 時間擋拌（以下，擋拌 b) した。擋拌 $\mathrm{a}$ 終了後，擋拌 $\mathrm{b}$ 開始前および擋拌 $\mathrm{b}$ 終了後の溶液中の $\mathrm{Al}$ をそれぞれ分析 することで， $\mathrm{Al}(\mathrm{OH})_{4}$ と $\mathrm{Cl}^{-}$の選択性の大小を判別した。

仮に, $\mathrm{Al}(\mathrm{OH}))_{4}$ に比べ $\mathrm{Cl}^{-}$の選択性が大きければ，撹拌 $\mathrm{b}$ 後の溶液中の $\mathrm{Al}$ は増加することになる。なお, 溶液中 の $\mathrm{Al}$ は先述した ICP-AES 法にて分析した。

\section{2 分析結果}

（1）HPC 中の陰イオンの分析結果

表一3に HPC 中の陰イオンの分析結果を示す。表に示

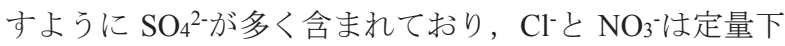
限值以下の低い濃度であった。硫黄（S）の原子量が 32.066AMU, 酸素 (O) の原子量が 15.9994AMU であり, $\mathrm{SO}_{4}{ }^{2-1} 2$ 価のマイナスイオンである。ここで, $\mathrm{AMU}$ と は原子質量単位であり, 微小な質量を表す単位である。 AER の官能基に $\mathrm{SO}_{4}{ }^{2-}$ が吸着する際は, 官能基 1 基あた りに $\mathrm{SO}_{4}{ }^{2-}$ は 1 価分だけ吸着する。すなわち, $\mathrm{SO}_{4}^{2-を ~ A E R ~}$ に吸着させるには AER の官能基は 2 基必要である。AER の官能基 1 基あたりに吸着する $\mathrm{SO}_{4}{ }^{2-}$ の化学当量は式(6) より, 48.03 である。水セメント比が $\mathrm{W} / \mathrm{C}=60 \%, \mathrm{SO}_{4}{ }^{2-}$ の化学当量が 48.03 であるから, 式(7)より, セメント $1 \mathrm{~g}$

\section{表－3 HPC 抽出液中の陰イオン濃度}

\begin{tabular}{|c|c|c|}
\hline $\mathrm{SO}_{4}{ }^{2-}(\mathrm{mg} / \mathrm{L})$ & $\mathrm{Cl}^{-}(\mathrm{mg} / \mathrm{L})$ & $\mathrm{NO}_{3}{ }^{-}(\mathrm{mg} / \mathrm{L})$ \\
\hline 4400 & $<250$ & $<250$ \\
\hline
\end{tabular}

$(32.066 / 2)+4 \times(15.9994 / 2)=48.0318 \doteqdot 48.03 \quad$ (6) $(60 / 100) \times\left(4400 \times 10^{-6}\right) / 48.03 \times 10^{3}=0.055$ 
から溶出する $\mathrm{SO}_{4}^{2-1}$ は，最大で $0.055 \mathrm{meq}$ となる。

AER を体積混入率で 3\%混入したモルタルを作製する 際の配合は, 後述する表一7の H3 に相当し, モルタル 1 $\mathrm{m}^{3}$ に含まれる AER は $32 \mathrm{~kg}$ であるため, AERの体積混

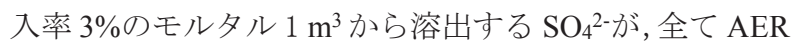
に吸着されると仮定した場合の $\mathrm{SO}_{4}{ }^{2-}$ の吸着量は, 表一4 に示す過程で算出され, 吸着可能な $\mathrm{Cl}^{-}$量の $25 \%$ を占める。

すなわち, セメント種別が HPC で AER の体積混入率 $3 \%$ モルタルの場合, $\mathrm{Cl}^{-}$が AER に吸着可能な交換容量 は，本来 AER が吸着できる容量の $75 \%$ 程度であること が明らかとなった。

（2）CAC 中の陰イオンの分析結果および選択性

表－5 に陰イオンの分析結果を示す。この結果から,

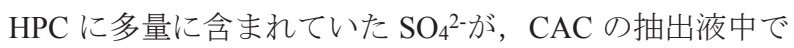
は定量下限值以下の低い濃度であることが明らかとなっ た。また, 表一6に $\mathrm{Al}(\mathrm{OH})_{4}$-濃度の測定結果を示す。こ

\section{表 -4 分析過程での算出手順と吸着量の算出結果}

\begin{tabular}{|l|l|}
\hline \multicolumn{1}{|c|}{ 分析過程での算出手順 } & \multicolumn{1}{c|}{ 算出結果 } \\
\hline $\mathrm{AER}$ の全交換容量 & $4.0 \mathrm{eq} / \mathrm{kg}$-樹脂 \\
\hline モルタル $1 \mathrm{~m}^{3}$ が吸着可能な $\mathrm{Cl}^{-}$ & $32 \mathrm{~kg} \times 4.0 \mathrm{eq} / \mathrm{kg}$-樹脂 $=$ \\
& $128 \mathrm{eq}$ \\
\hline モルタル $1 \mathrm{~m}^{3}$ から溶出する & $0.055 \mathrm{meq} \times 586 \mathrm{~kg} \times$ \\
$\mathrm{SO}_{4}{ }^{2-}$ (最大) & $1,000 \mathrm{~g} / \mathrm{kg}=32.2 \mathrm{eq}$ \\
\hline $\mathrm{SO}_{4}{ }^{2-}$ の吸着量 & $32.2 \mathrm{eq} \div 128 \mathrm{eq}=0.25$ \\
\hline
\end{tabular}

表－5 抽出液中の陰イオン濃度

\begin{tabular}{|c|c|c|c|}
\hline セメント & $\mathrm{SO}_{4}{ }^{2-}(\mathrm{mg} / \mathrm{L})$ & $\mathrm{Cl}^{-}(\mathrm{mg} / \mathrm{L})$ & $\mathrm{NO}_{3}{ }^{-}(\mathrm{mg} / \mathrm{L})$ \\
\hline CAC-C & $<250$ & $<250$ & $<250$ \\
\hline CAC-T & $<250$ & $<250$ & $<250$ \\
\hline
\end{tabular}

表 -6 溶液中の $\mathrm{Al}(\mathrm{OH})_{4}^{- \text {濃度 }}$

\begin{tabular}{|c|c|c|}
\hline \multirow{2}{*}{ セメント } & \multicolumn{2}{|c|}{$\mathrm{Al}(\mathrm{OH})_{4}^{-}(\mathrm{mg} / \mathrm{L})$} \\
\cline { 2 - 3 } & AER カラム入口 & AER カラム出口 \\
\hline CAC-C & 120 & 0.2 \\
\hline CAC-T & 140 & 0.2 \\
\hline
\end{tabular}

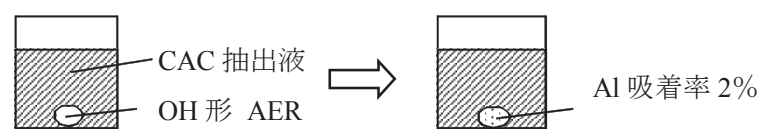

16 時間擋汼 $\mathrm{a}$

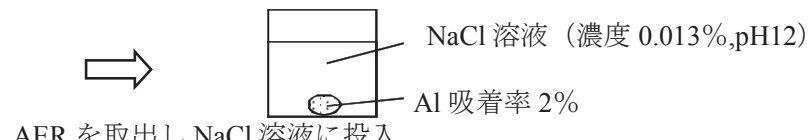

$\mathrm{AER}$ を取出し $\mathrm{NaCl}$ 溶液に投入

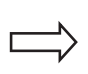

16 時間擋拌 $b$

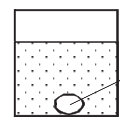

$\mathrm{Al}$ 吸着率 $0 \%$

図-1 $\mathrm{Al}(\mathrm{OH})_{4}^{-}$と $\mathrm{Cl}^{-}$の選択性の比較結果
の結果から， $\mathrm{AER}$ が $\mathrm{Al}(\mathrm{OH}) 4$ をを吸着することが明らか となった。さらに, 図ー1に $\mathrm{Al}(\mathrm{OH})_{4}^{-}$と $\mathrm{Cl}^{-}$との選択性を 比較した分析のフローおよび結果を示す。撹拌 $\mathrm{b}$ 後の $\mathrm{AER} \sim の \mathrm{Al}$ の吸着率が $0 \%$ となり, $\mathrm{Cl}^{-}$が優位的に吸着

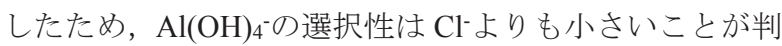
明し，仮に初期段階で $\mathrm{Al}(\mathrm{OH})_{4}^{-}$が AER に吸着しても $\mathrm{Cl}^{-}$ の AER への吸着には問題がないことが明らかとなった。

\section{3. 塩分浸漬実験}

\section{1 概要}

AER の $\mathrm{Cl}^{-}$吸着特性を明らかにするために AER を混合 したモルタル供試体を用いて塩分浸漬実験 4),5)を行った。 セメントは，HPC および高炉セメント（以下，BFS）と し, AER の混入率は体積比で 0 3\%の 4 種類とした。

表－7 に配合表を示し，供試体は図－2 に示すように 寸法は $10 \mathrm{~cm} \times 8 \mathrm{~cm} \times 10 \mathrm{~cm}$ である。塩分浸漬実験では, $10 \% \mathrm{NaCl}$ 水溶液を用い, 浸漬面は供試体の 1 面だけとし 他面はエポキシ樹脂にて被覆処理を施し,「浸漬 1 日十温 度 $20^{\circ} \mathrm{C}$ 湿度 $60 \%$ での乾燥 6 日」を 1 サイクルとした。測 定項目は全塩化物量および電子線マイクロアナライザ

（以下，EPMA）とし，全塩化物量の定量手法は JCI 法 6)を用い，測定時期は浸漬・乾燥の繰返し期間である材 齢 28 日，56日，84 日とした。既往の研究 5)では，この 供試体および浸漬実験条件のもと，浸漬面の表面からの 深さと全塩化物量との関係を述べているが，本章では， 供試体間および経時的な全塩化物量の変動から, AERの $\mathrm{Cl}^{-}$の吸着効果について明らかにするものである。なお,

\section{表－7＼cjkstart塩分浸漬実験に用いた供試体の種別および配合}

\begin{tabular}{|c|c|c|c|c|c|}
\hline \multirow{2}{*}{ 供試体 } & \multirow{2}{*}{$\begin{array}{l}\text { セメン } \\
\text { ト種別 }\end{array}$} & \multicolumn{4}{|c|}{ 単位量 $\left(\mathrm{kg} / \mathrm{m}^{3}\right)$} \\
\hline & & セメント & 水 & 細骨材 & $A E R \approx 2$ \\
\hline $\mathrm{H} 0$ & HPC & \multirow{2}{*}{586} & \multirow{2}{*}{293} & \multirow{2}{*}{1,259} & \multirow{2}{*}{$\begin{array}{c}0 \\
(0 \%)\end{array}$} \\
\hline B0 & BFS & & & & \\
\hline H1 & HPC & \multirow{2}{*}{586} & \multirow{2}{*}{293} & \multirow{2}{*}{1,234} & \multirow{2}{*}{$\begin{array}{c}11 \\
(1 \%)\end{array}$} \\
\hline B1 & BFS & & & & \\
\hline $\mathrm{H} 2$ & HPC & \multirow{2}{*}{586} & \multirow{2}{*}{293} & \multirow{2}{*}{1,209} & \multirow{2}{*}{$\begin{array}{c}21 \\
(2 \%)\end{array}$} \\
\hline B2 & $\mathrm{BFS}$ & & & & \\
\hline $\mathrm{H} 3$ & HPC & \multirow{2}{*}{586} & \multirow{2}{*}{293} & \multirow{2}{*}{1,183} & \multirow{2}{*}{$\begin{array}{c}32 \\
(3 \%)\end{array}$} \\
\hline B3 & BFS & & & & \\
\hline
\end{tabular}

$※ 2 （ ）$ 内は，体積混入率

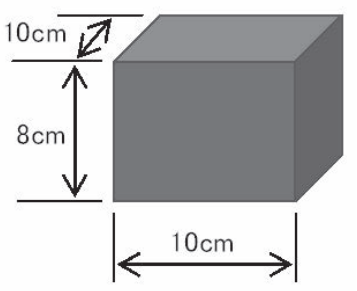

図-2 塩分浸漬実験用供試体 
全塩化物の測定に用いる試料は, 供試体の塩分浸漬面か ら深さ $(0 \sim 10 \mathrm{~mm}), \quad(13 \sim 23 \mathrm{~mm}), \quad(26 \sim 36 \mathrm{~mm}), \quad(39 \sim$ $49 \mathrm{~mm})$ の各層毎にスライスカットし粉砕して作製した。 EPMA は，全塩化物量の定量結果で得られた現象を面 的に再検証するために, 「JSCE-G574-2005 EPMA 法に よるコンクリート中の元素の面分析方法(案)」に基づい た分析を行った。既往の研究7)では, セメントにCACを 使用したモルタルでの結果を論じているが，本研究にお いてはセメントに HPC を使用し, 配合は表ー7 中の H0, $\mathrm{H} 3$ と同様のものとし, 先述した塩分浸漬後の浸漬・乾燥 の繰返し期間である材齢 84 日時点で，本分析を行った。

AER を混入したモルタルの圧縮強度は, 表一7の配合 ごとに, HPC 使用で浸漬・乾燥の繰返し期間である材齢 14 日，BFS 使用で浸漬・乾燥の繰返し期間である材齢 28 日において JIS A 1108 による試験を行った。試験結果 を図一 3 に示す。

AER の増大に伴い圧縮強度が僅かに低下寸る傾向が 認められる。本研究では AER の混入率と圧縮強度との関 係を論じるにとどまっているが，圧縮強度が低下する理 由としては, AER が混入されることによる遷移体の増加,

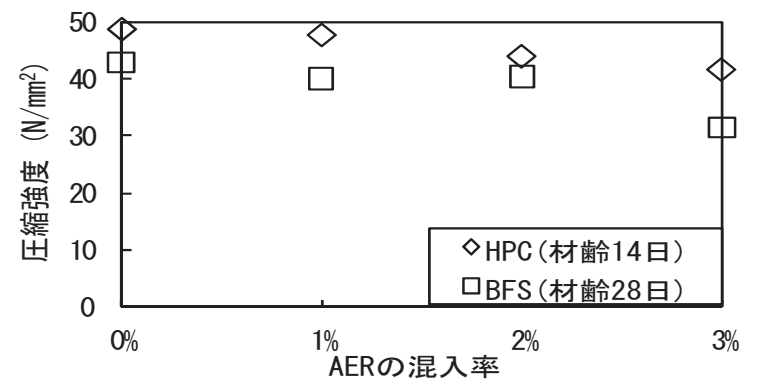

図-3 AER の混入率と圧縮強度との関係

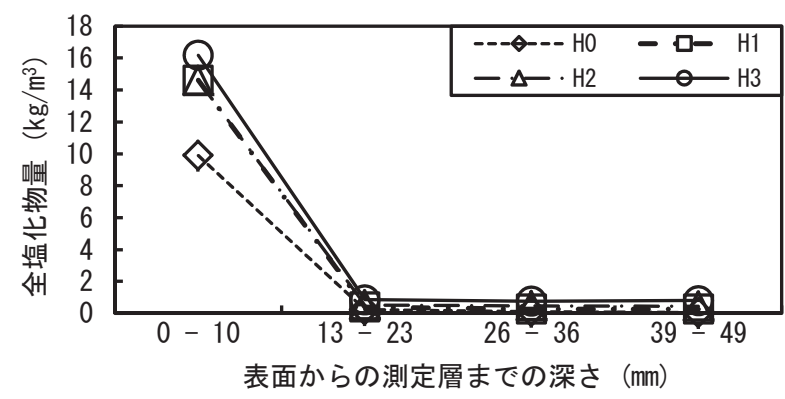

（a）HPC 使用（表面 49mm）

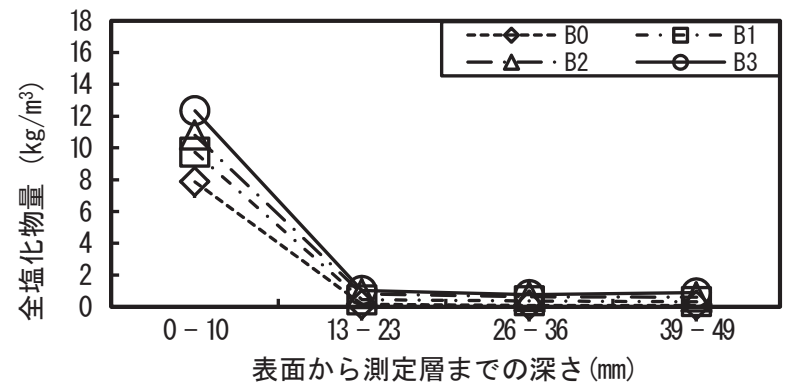

（c）BFS 使用（表面 49mm）
空隙量の増加, AER とセメントペーストとの界面の影響 が考えられる。今後，水銀圧入法等による空隙量の定量 を行う等により，圧縮強度の低下を理論的に明らかにし ていく必要があると認識している。さらに, セメントの 凝結試験を JIS R 5201-1997 により行ったところ, 凝結の 始発が 3h-15mm，凝結の終結が 4h-45mm となり，コン クリート標準示方書【規準編】の規準 ${ }^{8)}$ を満足している ことが明らかとなった。

\subsection{AER の混入量と全塩化物量の関係}

（1）セメント種別ごとの全塩化物量

図－4に浸漬・乾燥の繰返し期間である材齢 84 日時点 での全塩化物量を示す。図ー4(b)，(d) はそれぞれ同図 (a)，（c)のグラフにおいて $(0-10 \mathrm{~mm})$ の範囲を除いて全 塩化物量の尺度を拡大したものである。なお，図４－の 縦軸の值は，(0-10mm)，（13-23mm），（26-36mm）, (39-49mm) の各厚さをもった四辺体を微粉砕した試料 での值であるため，横軸はこのような表記とした。

図ー4(a)および(c)より，HPC 使用のモルタルおよび BFS 使用のモルタルとも，概ね表面からの深さが深くな るにつれて全塩化物量が少なくなる傾向を示している。 浸漬面の表層部分である 0-10mm ではAERの有無および 混入量の大小と全塩化物量の大小に明確な違いが表れ, AER の混入量が多くなるほど全塩化物量は多くなる。こ れは AER による $\mathrm{Cl}^{-}$の吸着作用が浸漬面の表層部分では 活発であり,この層に多くの $\mathrm{Cl}^{-}$留めておく働きが生じ ているものと考えられる。この現象に比べて, 図一4(b) および(d)に示すとおり，13mm 以深では全塩化物量は $1.1 \mathrm{~kg} / \mathrm{m}^{3}$ 以下の小幅な領域で変動しており, AERの有無 および混入量の大小と全塩化物量との関係は，0-10mm 部分と同様であるがその差は小さくなることがわかる。

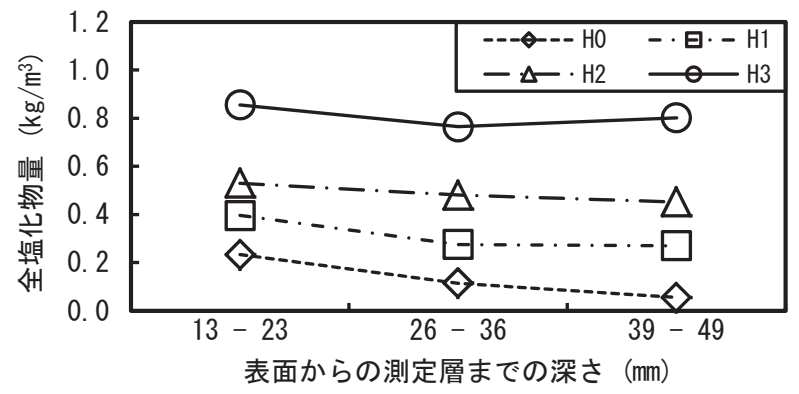

(b) HPC 使用 $(13 \sim 49 \mathrm{~mm})$

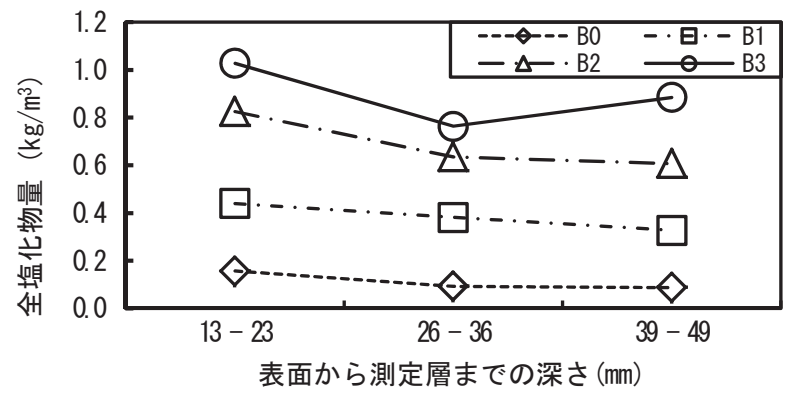

(d) BFS 使用 $(13 \sim 49 \mathrm{~mm})$

図-4＼cjkstart表面からの測定層ごとの全塩化物量 
すなわち, AER を多く混入するほど浸透塩分量が多く なることが明らかとなった。また，13mm 以深の領域で は HPC 使用の供試体と BFS 使用の供試体では，全塩化 物量の差異は僅かであり, セメント種別の違いによる全 塩化物量の違いは見られなかった。

（2）経時的な全塩化物量の変動

図－5 に HPC を用いた供試体 $\mathrm{H} 0 ， \mathrm{H} 1 ， \mathrm{H} 2$ ，および H3 における経時的な全塩化物量の変動結果を示寸。図一 5 (b)，(d)，（f），(h）はそれぞれ同図（a)，(c)，(e)， (g) のグラフにおいて $(0-10 \mathrm{~mm})$ の範囲を除いて全塩 化物量の尺度を拡大したものである。なお，図－5の縦

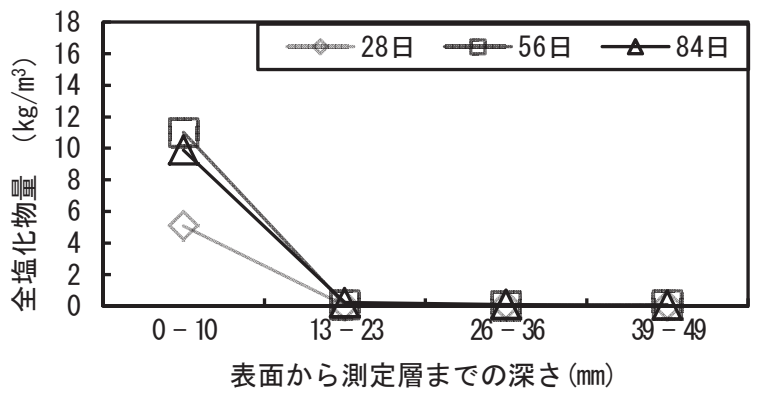

(a) HO（表面 49mm)

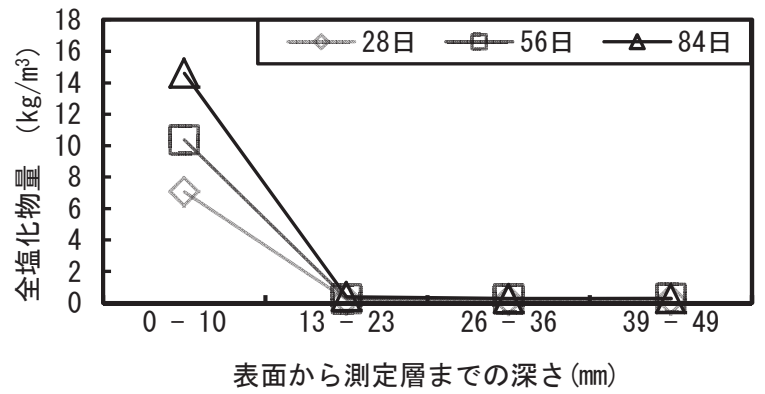

(c) H1（表面～49mm）

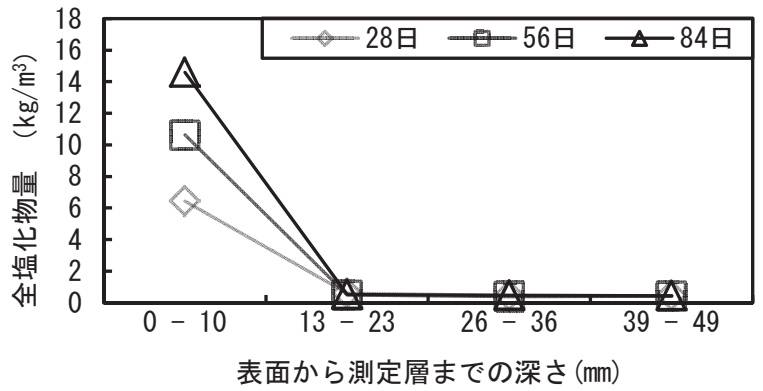

(e) H2（表面 49mm)

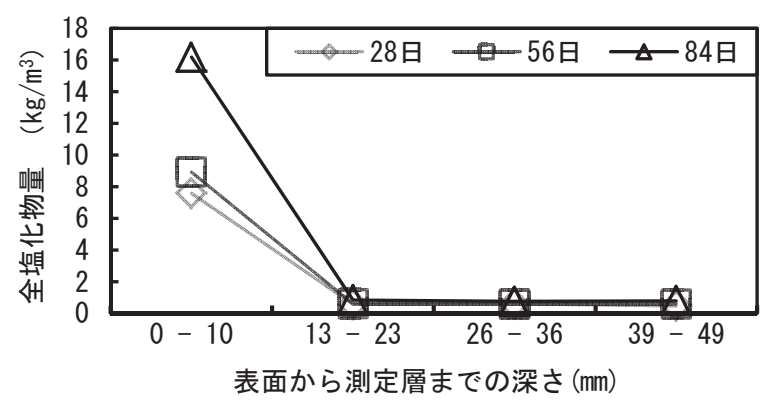

(g) H3 (表面 49mm)
軸の值は, (0-10mm), (13-23mm), (26-36mm), (39-49mm) の各厚さをもった四辺体を微粉砕した試料での值である ため，横軸はこのような表記とした。図－5（a)，(c)，

(e)，および（g）から，浸漬面の表層部分にあたる 0-10mm 部分では, 浸漬・乾燥の繰返し期間である材齢 28 日から 84 日にかけて全塩化物量は，概小 2 倍程度増 大することが明らかとなった。図－5 (b)，(d)，(f), および (h) から，13-49mm 部分での全塩化物量の変化 を見てみると, H3 を除いて浸漬・乾燥の繰返し期間であ る材齢による全塩化物量の変化は小さく, 概ね浸漬・乾 燥の繰返し期間である材齢 28 日程度で塩化物の変動は

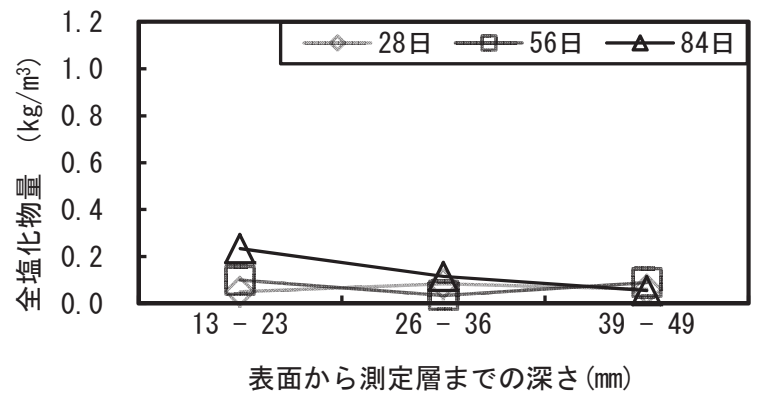

(b) HO (13 49mm)

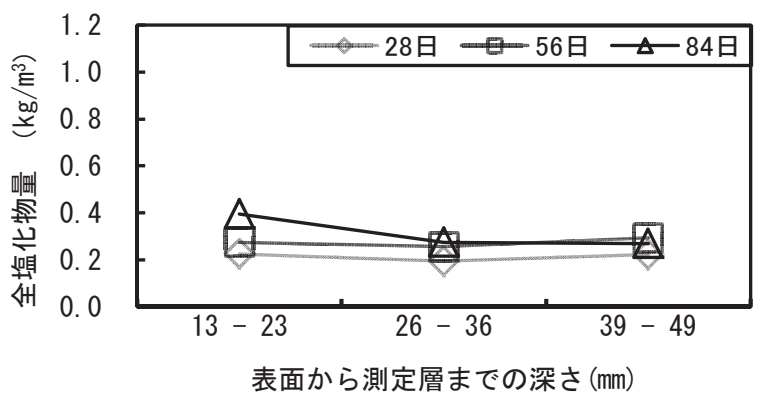

(d) $\mathrm{H} 1 \quad(13 \sim 49 \mathrm{~mm})$

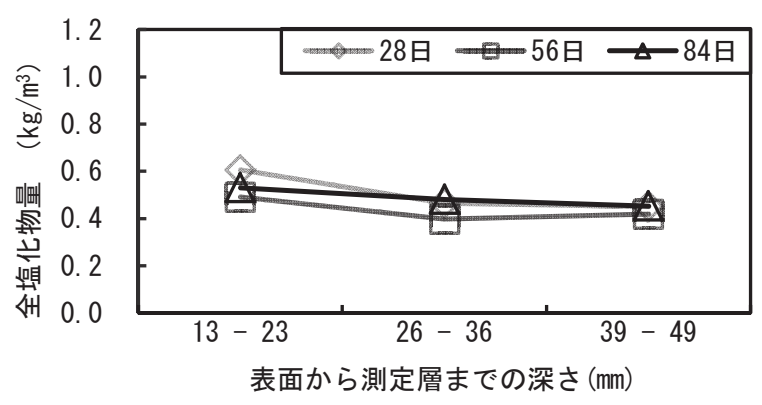

(f) $\mathrm{H} 2(13 \sim 49 \mathrm{~mm})$

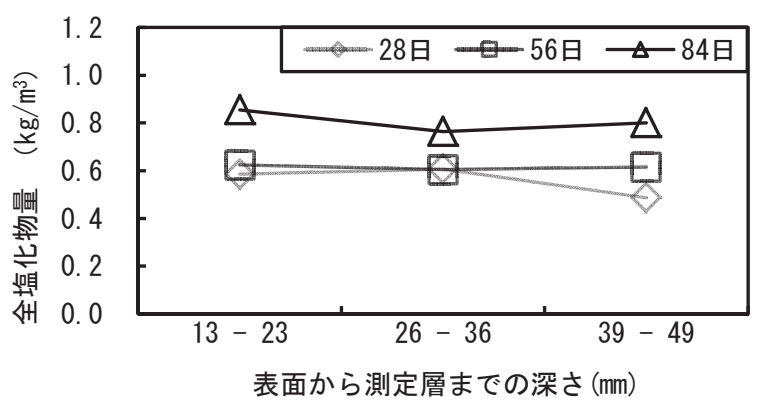

(h) H3 $(13 \sim 49 \mathrm{~mm})$ 
終了するものと考えられる。

図ー6にBFS を用いた供試体 B0，B1，B2，および B3 における経時的な全塩化物量の変動結果を示す。図一6 (b)，(d)，（f），(h）はそれぞれ同図（a)，（c），(e), (g) のグラフにおいて $(0-10 \mathrm{~mm})$ の範囲を除いて全塩 化物量の尺度を拡大したものである。なお, 図ー6の縦 軸の值は, (0-10mm), (13-23mm), (26-36mm), (39-49mm) の各厚さをもった四辺体を微粉砕した試料での值である ため，横軸はこのような表記とした。図一6（a)，(c)，

(e)および $(\mathrm{g})$ から, 浸漬面の表層部分にあたる 0-10mm 部分での浸漬・乾燥の繰返し期間である材齢 28 日から

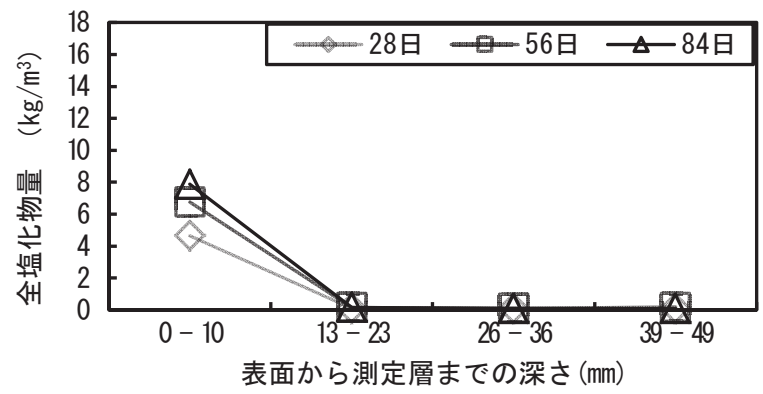

(a) BO（表面 49mm)

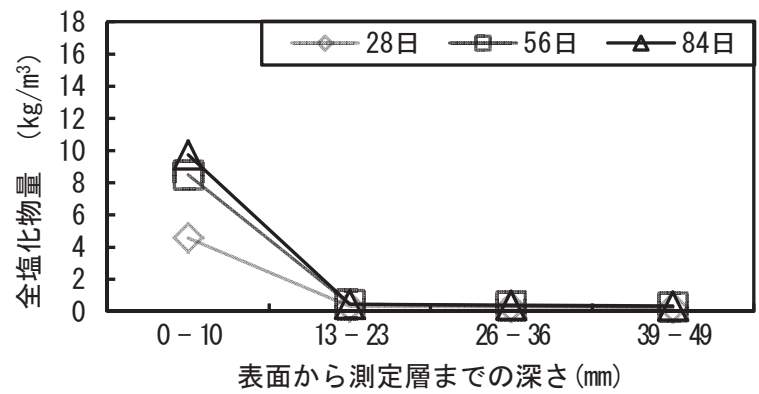

（c）B1（表面～49mm）

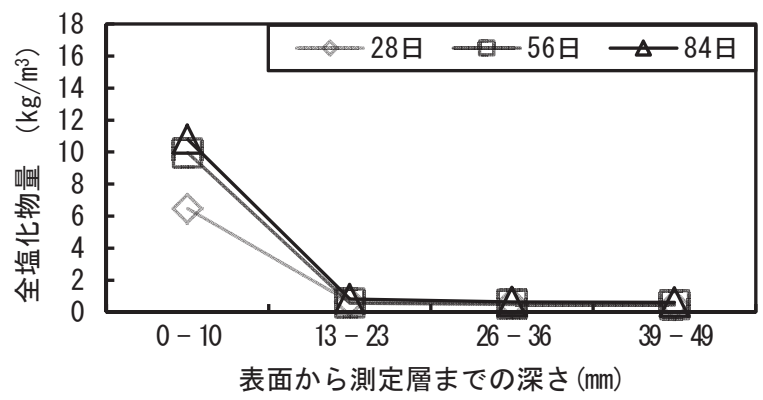

（e）B2（表面～49mm)

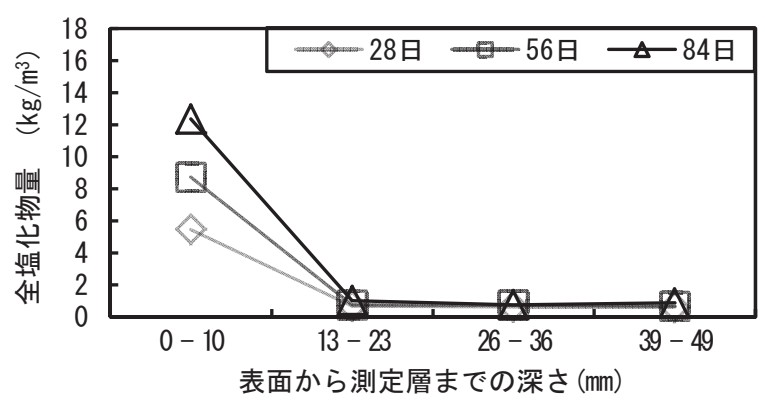

（g）B3 (表面 49mm)
84 日にかけて全塩化物量は，B0 では約 1.8 倍に対して B3 では 2.2 倍となっている。また, 浸漬・乾燥の繰返し 期間である材齢 56 日から 84 日へかけての全塩化物量の 増加分が，B0，B1，B2 の各供試体では僅かであるのに 対して，B3 供試体では大きくなった。図ー6 (b)，(d), (f)，および (h) からは，(13-23mm）部分および (26-36mm) 部分での全塩化物量の変動は AER を混入す ることによって概して浸漬・乾燥の繰返し期間である材 齢が経つほど全塩化物量の值が大きくなる傾向にある。

これは，HPCを用いた場合と同じである。また，AER を体積混入率 3\%とした場合（供試体 B3）では混入しな

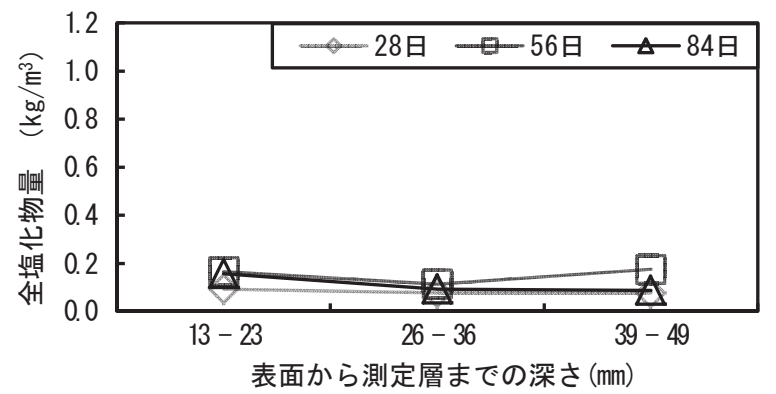

(b) BO (13 49mm)

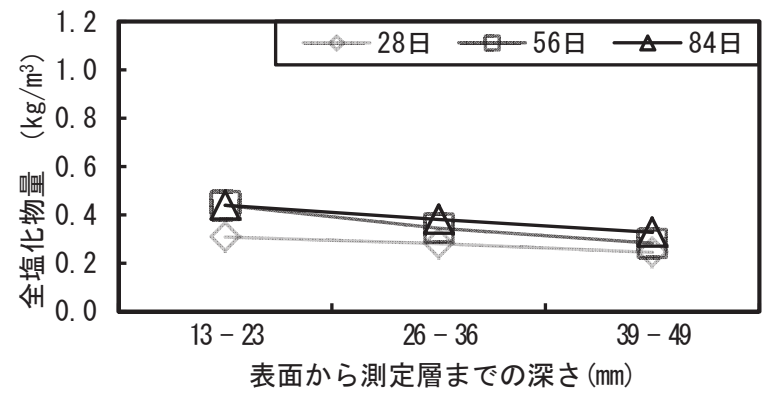

(d) B1 (13 49mm)

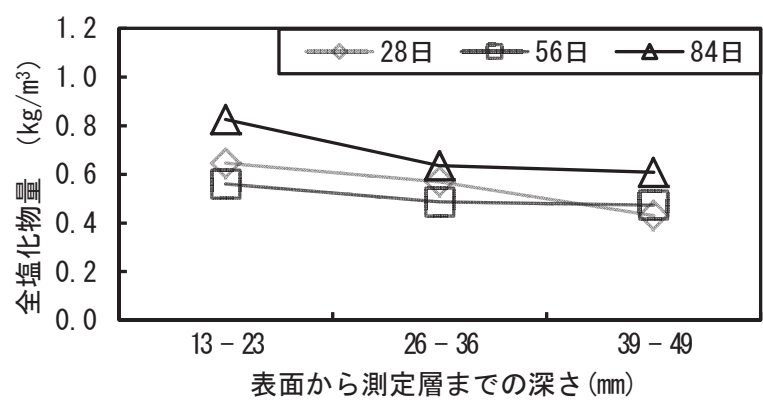

(f) B2 $(13 \sim 49 \mathrm{~mm})$

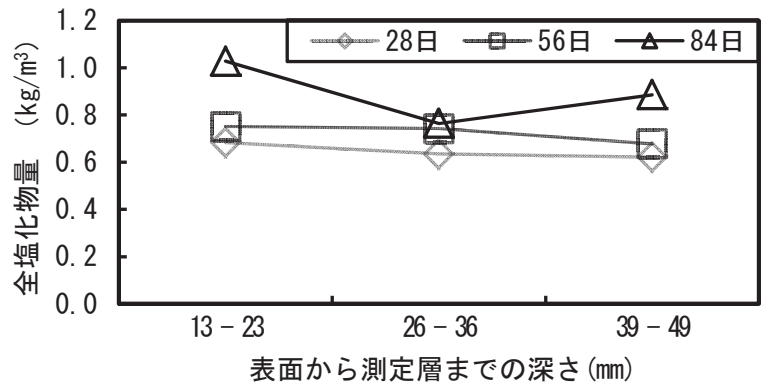

(h) B3 $(13 \sim 49 \mathrm{~mm})$ 
い場合（供試体 B0）に比べて, 塩分浸漬表面からの深さ が $13 \mathrm{~mm}$ より深い部分において, 浸漬・乾燥の繰返し期 間である材齢 84 日での全塩化物は 5 倍程度となることが 明らかとなった。以上により, AER がより多くの $\mathrm{Cl}^{-} を$ 呼び込むという現象が明らかとなり，この現象は，モル タルの練混ぜ直後だけでなく, 経時的に継続していると 考えられ, AERの混入量が多くなるに従い全塩化物量の 増加割合が大きくなることが明らかとなった。セメント 種別の違いによる全塩化物量の違いは, 表層部に相当す る 0-10mm 部分で表れ, BFS 使用の方が HPC 使用に比べ て少ない傾向にある。これは, BFS が HPC と比べて高炉 スラグの影響により塩化物をフリーデル氏塩として固定 化する特性に優れ，塩化物イオンの拡散係数が小さい9) ためと考えられる。

\subsection{EPMA による塩化物の面分析の結果}

図-7 に $\mathrm{H} 0$ 供試体, 図-8 に $\mathrm{H} 3$ 供試体の $\mathrm{Cl}^{-}$の分析結 果を示す。各図の (a) は $7 \mathrm{~cm} \times 8 \mathrm{~cm}$ のサイズでの分析結果 であり, 各図の (b) は各々の (a) の $\square$ 部分 $(2 \mathrm{~cm} \times 2 \mathrm{~cm})$ を抽 出し拡大表示させた画像である。各図の右側の表示は塩 化物の濃度の大小を示す尺度であり, 黒色 $\rightarrow$ 赤色と色彩 が遷移するほど塩化物濃度が濃いことを表し，「Area\%」 は「ClLevel が 0〜25」から「ClLevel が 200 以上」の各 範囲にあたる部分の面積が分析サイズ全面積に占める割 合（比率）を表す。

各図の (a)および各図の (b)の比較から, AERを体積比 で 3\%混入させた供試体は混入させていない供試体と比
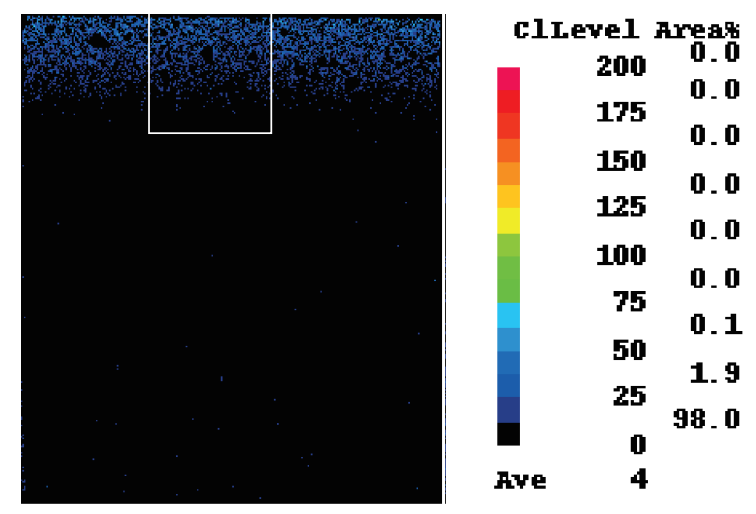

(a) 分析サイズ $7 \mathrm{~cm} \times 8 \mathrm{~cm}$
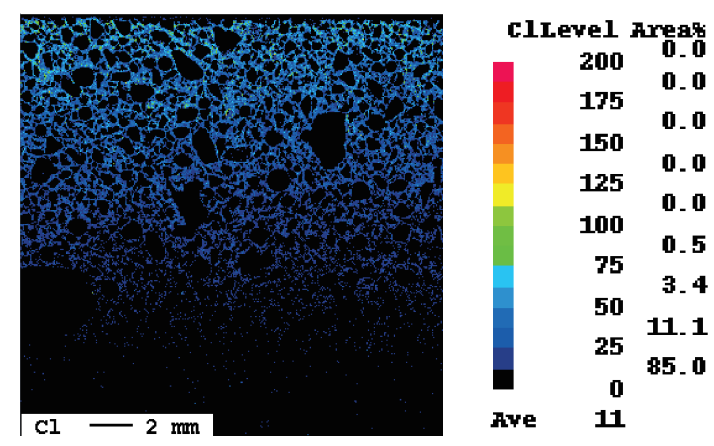

(b) 分析サイズ $2 \mathrm{~cm} \times 2 \mathrm{~cm}$ 図-7 AER 未混入の EPMA 結果
ベて, $\mathrm{Cl}^{-}$の平均 Level が大きい, すなわち濃度が濃くな るという結果を得た。すなわち, 3.2 で述べた全塩化物量 の実験結果の妥当性が EPMA により裏付けされたので ある。

\section{4. 解析的検討}

\section{1 解析概要}

（1）概要およびモデルの定義

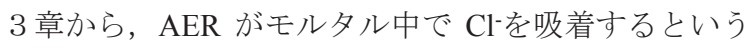
現象が定量的に明らかとなった。ここでは，AERによる $\mathrm{Cl}^{-}$の固定化を考慮したうえで, AER 混入モルタルにおけ る塩化物イオンの移動をフィックの拡散方程式をもとに シミュレーションすることとした。

既往の研究 10) と同様に, 飽和状態で塩化物の質量保存 を考えると, 1 次元の自由塩化物 $C_{f}\left(\mathrm{~kg} / \mathrm{m}^{3}\right)$ の移動は, 式（8）と表される。

$$
\frac{\partial C_{f}}{\partial t}=\frac{\partial}{\partial x}\left[D_{\mathrm{Cl}} \frac{\partial C_{f}}{\partial x}\right]-\frac{\partial C_{b}}{\partial t}
$$

ここで, $C_{b}$ : 固定化塩化物量 $\left(\mathrm{kg} / \mathrm{m}^{3}\right), D_{\mathrm{Cl}}$ : モルタル 中の自由塩化物の拡散係数 $\left(\mathrm{m}^{2} / \mathrm{s}\right)$ である。

後述するように, 固定塩化物 $C_{b}$ を自由塩化物 $C_{f}$ の関 数とし, $D_{\mathrm{Cl}}$ は位置 $x$ に依存しないと仮定すると, 式 (8) は, 式（9）という単純な微分方程式になる。
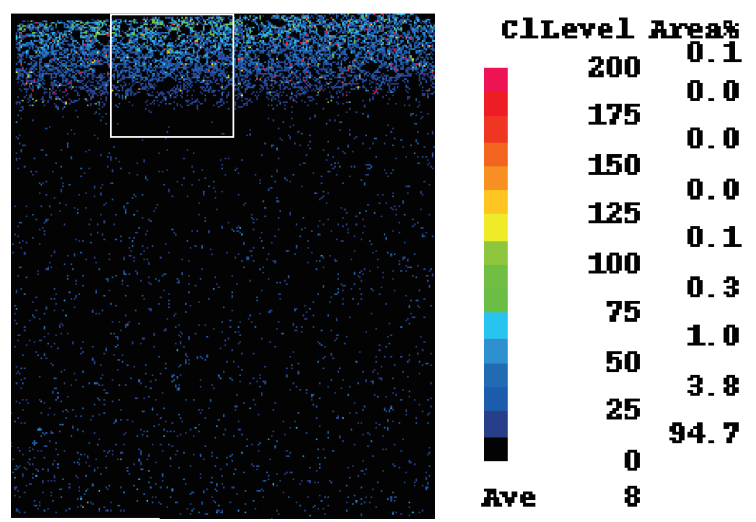

(a) 分析サイズ $7 \mathrm{~cm} \times 8 \mathrm{~cm}$

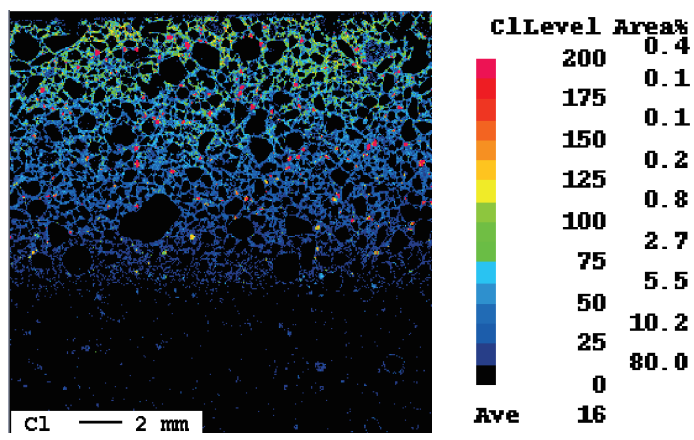

(b) 分析サイズ $2 \mathrm{~cm} \times 2 \mathrm{~cm}$

図-8 AER3\%混入の EPMA 結果 


$$
\frac{\partial C_{f}}{\partial t}=\left[\frac{D_{c l}}{1+\frac{\partial C_{b}}{\partial C_{f}}}\right] \frac{\partial^{2} C_{f}}{\partial x^{2}}
$$

これを差分法により解くことで, 自由塩化物 $C_{f}$ が求ま り, $C_{f}$ の関数で表される固定塩化物 $C_{b}$ も算出できるので, これらを足し合わせることで, AER 混入モルタル中の全 塩化物量 $C_{t}\left(\mathrm{~kg} / \mathrm{m}^{3}\right)$ を求めることができる。ただし, 式

（9）を解くうえで, 固定化容量を表寸 $\partial C_{b} / \partial C_{f}$ を求め る必要があるので，以下述心゙る。

(2) 塩化物の固定（結合）等温線

AER 混入モルタルにおける固体化塩化物は, セメント 硬化体に固定される塩化物と, AER に吸着し固定化され る塩化物からなる。ここでは, AER 混入による固定化の 評価を目的に, 式（9）における固定化塩化物 $C_{b}$ は AER に吸着した塩化物のみであるという単純な仮定をするこ とで, 拡散解析を行った。よって, 本解析において, 上 記の $D_{\mathrm{cl}}$ はセメント硬化体に固定化された塩化物イオン を含有した見掛けの拡散係数となる。

自由塩化物に対する AER の吸着能力を検討するため, 異なる塩化物イオン濃度を持った $\mathrm{NaCl}$ 水溶液に, $\mathrm{AER}$ を体積混入率にして $1 \%, 2 \% ， 3 \%$ を混入し，溶液中の塩 化物イオン濃度を計測した。図ー9に結果を示す。AER の体積混入率が大きくなるにつれ塩化物の吸着量は大き くなり，溶液中の塩化物濃度が高濃度時の等温曲線の勾 配がゼロに近づいている。

溶液中の塩化物濃度を自由塩化物とみなし, AERに吸 着した塩化物を固定塩化物と考え, この吸着挙動を単一 層での吸着と考え, 式（10）で表される Langmuir の吸着 等温線で表現することとする。

$$
C_{b}=\frac{\alpha C_{f}}{1+\beta C_{f}}
$$

ここで， $\alpha, \beta$ : 固定化係数である。

式（10）を式（11）のように変形し, $C_{f} / C_{b}$ と $C_{f}$ の関 係を求めると, 図一10 のようになり, AER の各体積混 入率に応じた固定化係数が表－8のように求まる。

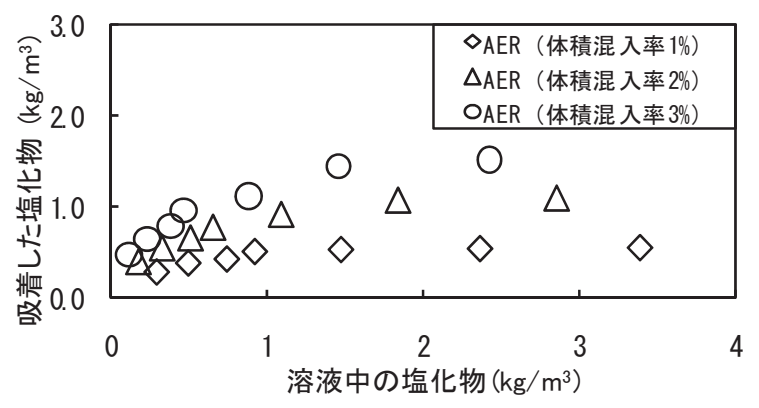

図-9 溶液中の塩化物と AER が吸着した塩化物の関係

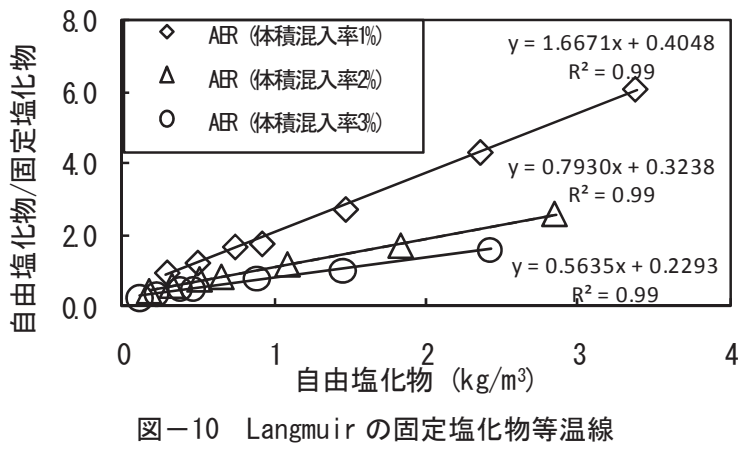

表-8 Langmuir 等温線線形回帰解析による固定化係数

\begin{tabular}{|c|c|c|c|c|}
\hline AER 体積混入率 & $\alpha$ & $\beta$ & $1 / \alpha$ & $\beta / \alpha$ \\
\hline $1 \%$ & 2.470 & 4.118 & 0.4048 & 1.6671 \\
\hline $2 \%$ & 3.088 & 2.449 & 0.3238 & 0.793 \\
\hline $3 \%$ & 4.361 & 2.457 & 0.2293 & 0.5635 \\
\hline
\end{tabular}

表 -9 塩化物イオンの拡散係数

\begin{tabular}{|c|c|c|}
\hline & HPC 使用 & BFS 使用 \\
\hline$D_{\mathrm{cl}}\left(\mathrm{m}^{2} / \mathrm{s}\right)$ & $2.65 \times 10^{-12}$ & $2.44 \times 10^{-12}$ \\
\hline
\end{tabular}

$$
\frac{C_{f}}{\mathrm{C}_{\mathrm{b}}}=\frac{\beta C_{f}}{\alpha}+\frac{1}{\alpha}
$$

(3) 塩化物イオンの拡散係数

$D_{\mathrm{cl}}$ は本来自由塩化物の拡散係数であるが,「4.1(2)」で 述べたように，式（9）における固定化塩化物 $C_{b}$ は AER に吸着した塩化物のみという仮定のもと, $D_{\mathrm{cl}}$ をセメント 硬化体に固定化された塩化物イオンを含有した見掛けの 拡散係数とすると, AER を加えていないモルタルの全塩 化物 $C_{t}$ の拡散方程式は，式（12）と表すことができる。

$$
\frac{\partial C_{t}}{\partial t}=D_{\mathrm{cl}} \frac{\partial^{2} C_{t}}{\partial x^{2}}
$$

よって, AER を加えていないモルタルの位置 $x(\mathrm{~m})$, 時間 $t(\mathrm{~s})$ の全塩化物 $C_{t}\left(\mathrm{~kg} / \mathrm{m}^{3}\right)$ は, 式（13）で表され る。

$$
C_{t}=C_{0}\left\{1-\operatorname{erf}\left(\frac{x}{2 \sqrt{D_{\mathrm{cl}} \cdot t}}\right)\right\}
$$

ここで， $C_{0}$ : モルタル表面の塩化物イオンである。

この予測式と AER を加えていない供試体 H0, B0 の塩 分浸漬実験を比較し, $D_{\mathrm{cl}}$ を最小二乗法によって回帰する と, 表一9 のようになった。上記の固定塩化物の仮定の もと，この拡散係数を AER 混入モルタルに適用した。 


\section{2 解析結果および実験値との比較}

4.1 で述べた解析手法で, AER 混入モルタルにおける 塩化物浸透を計算した。図ー11に, セメントに HPCを 用いた供試体についての材齢 84 日経過時の塩分浸漬実 験結果と計算結果を AER の混入率ごとに示し, 図ー12 に，セメントに BFS を用いた供試体についての材齢 84 日経過時の塩分浸漬実験結果と計算結果を AER の体積 混入率ごとに示す。塩分浸漬実験值は供試体表面から (0-10mm), (13-23mm) 等の区間における平均值を示し ている。

図ー11 から，単純に固定化塩化物をAER に吸着した 塩化物のみと仮定した場合, 解析結果は塩分浸漬実験值 の傾向と概ね一致している。一方で, 高炉スラグ微粉末 をセメントと置換した場合, 解析值の方が実験值を上回 っている（図ー12）。これは，高炉スラグ微粉末を混入 した場合, 細孔溶液にある Cl-以外のイオンが AER によ る $\mathrm{Cl}^{-}$の固定化を阻害する影響が考えられ, $\mathrm{NaCl}$ 水溶液 で評価した固定化能力が十分発揮されなかったことなど が原因として挙げられる。また, 固定化塩分はAER に吸 着した塩化物のみという単純な仮定も影響していると考 えられ, HPC 使用の場合も含め, AER 混入モルタルの細 孔中の自由塩化物と固定化塩化物の関係を高圧抽出法な ど 12)によって求め, 解析の精度を高める必要があると認 識している。
5. A E Rを混入したモルタルによる既設塩 化物含有モルタル内部からの塩分移動に関 する実験

\section{1 実験内容}

以上で述べたように, AER をモルタルに混入し塩分環 境下に曝した場合，無混入の場合に比べて，より多くの 塩化物イオンがモルタル中に浸透することが明らかとな った。本研究では，このような AER による塩分移動の現 象を, 塩害を受けた既設コンクリート構造物に適用し, 既設コンクリート中に浸透した塩分をコンクリート表面 へ移動させ，除塩できないかどうかを検討することとし た。すなわち，図ー13 に示すように塩害を受けた既設 $\mathrm{RC}$ 構造物を模擬するため，あらかじめ塩分（ $\mathrm{NaCl})$ を 含有させたモルタルに補修材として用いることを想定し た AER が混入されたモルタルを貼り付けた供試体を作 製し, 経時的に塩化物量を測定することとした。ここで,

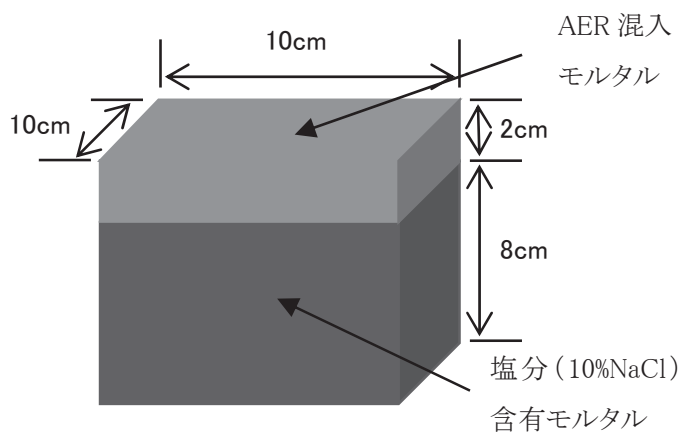

図-13 供試体概要

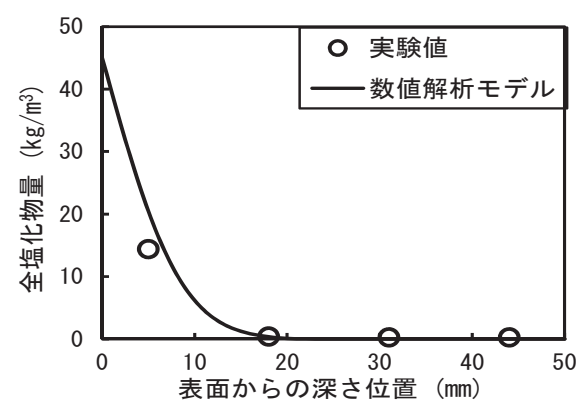

(a) AER1\%混入

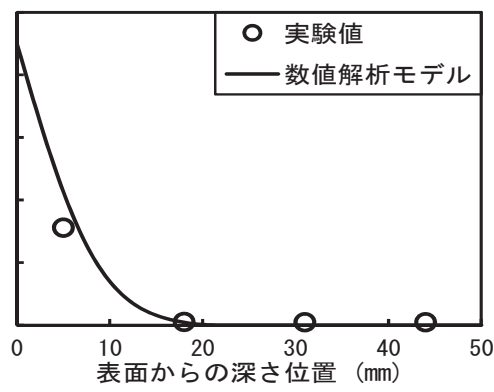

(b) AER2\%混入

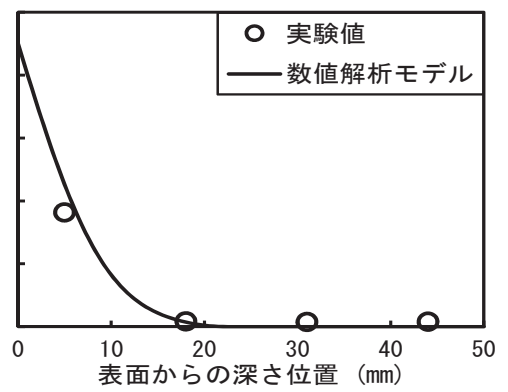

(c) AER3\%混入

図-11 全塩化物量の実験結果と解析結果との比較 (HPC 使用)

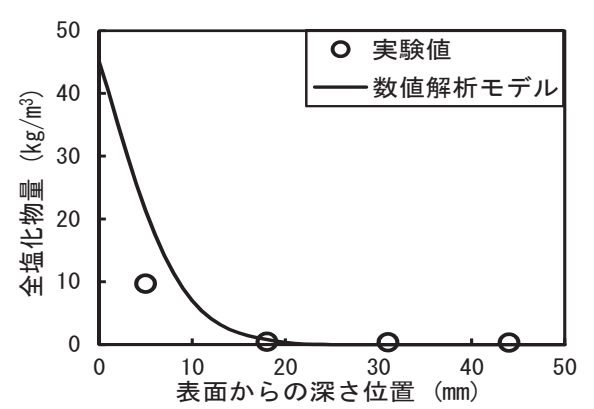

(a) AER1\%混入

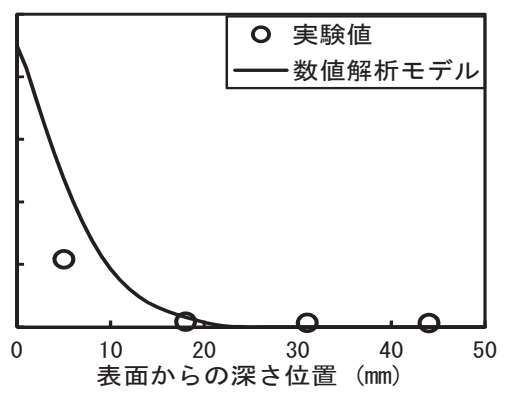

(b) AER2\%混入

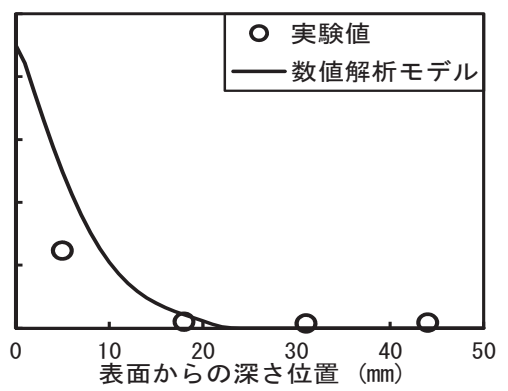

(c) AER3\%混入

図-12 全塩化物量の実験結果と解析結果との比較 (BFS 使用) 
本実験の主な目的は，AER を補修材に混入させて既設 RC 構造物中の塩化物を引き出すという間接的な特性を持ち 合わせているのかどうかを検証するため，このような供 試体を用いた。表ー10 塩分含有モルタルと AER 混入 モルタルの配合を示す。供試体の要因は, 塩分含有モル タル中の塩分 $(\mathrm{NaCl})$ 量を $2 \mathrm{~kg} / \mathrm{m}^{3}$ と $4 \mathrm{~kg} / \mathrm{m}^{3}$ の 2 ケース, AER 混入モルタル中の AER の量を $0 \mathrm{~kg} / \mathrm{m}^{3}$ と $32 \mathrm{~kg} / \mathrm{m}^{3}$ の 2 ケースで, 計 4 ケースを設定した。塩分含有モルタル の打継ぎ面はコテ仕上げとし, 貼付け側のモルタルを打 ち継ぐ場合は，打継ぎ面のレイタンスなどを除去し，湿 潤状態にして打ち継いだ。塩化物含有モルタルの初期養 生条件としては, 蒸発を防止するため表面をラップ養生 した。また, 全塩化物量の測定は, 貼付け側のモルタル を打ち継いだ後，28日，140日，330日経過した後，貼 付けモルタル側（図ー13 の供試体上面）から 1 層あたり $8 \mathrm{~mm}$ ずつコンクリートカッターで切断し, 微粉砕した試 料を用いて JCI 法による分析 ${ }^{6}$ にて行った。

\begin{tabular}{|c|c|c|c|c|c|c|}
\hline \multicolumn{7}{|c|}{ 表 -10} \\
\hline & \multirow{2}{*}{ 供試体 } & \multicolumn{5}{|c|}{ 単位量 $\left(\mathrm{kg} / \mathrm{m}^{3}\right)$} \\
\hline & & セメント & 水 & 細骨材 & $\mathrm{NaCl}$ & AER \\
\hline \multirow{2}{*}{ IA 1} & 塩分含有側 & \multirow{2}{*}{586} & 291 & 1,259 & 2 & - \\
\hline & 貼付け側 & & 293 & 1,259 & - & 0 \\
\hline \multirow{2}{*}{ IA 2} & 塩分含有側 & \multirow{2}{*}{586} & 291 & 1,259 & 2 & - \\
\hline & 貼付け側 & & 293 & 1,183 & - & 32 \\
\hline \multirow{2}{*}{ IB1 } & 塩分含有側 & \multirow{2}{*}{586} & 289 & 1,259 & 4 & - \\
\hline & 貼付け側 & & 293 & 1,259 & - & 0 \\
\hline \multirow{2}{*}{ IB2 } & 塩分含有側 & \multirow{2}{*}{586} & 289 & 1,259 & 4 & - \\
\hline & 貼付け側 & & 293 & 1,183 & - & 32 \\
\hline
\end{tabular}

打継ぎの材齢は，塩分含有側モルタルを打込んだ翌日 に AER 含有側のモルタルを打込んでから 2 日後からの 日数と定義した。また，打継ぎ後の供試体の含水状態お よび保管方法としては，水で湿らせた布（ウエス）で供 試体を包み, 適宜水分供給して, イオンの移動が促進す るよう室内で保管・管理した。

\section{2 実験結果}

図ー14 に供試体 IA1，IA2，IB1，およびIB2 について， 貼付けモルタルを打ち継ぎ後，28 日，140日，330日経 過した時点の各断面位置と全塩化物量との関係を示す。 図中の深さとは, 図一13 の供試体において上面からの距 離を示している。なお, 図ー14の縦軸の值は, (0-8mm),

(11-19mm), (22-30mm), (33-41mm) の各厚さをもっ た四辺体を微粉砕した試料での值であるため, 横軸はこ のような表記とした。図ー14 (a)〜（f）から，打ち継ぎ 後, 材齢 28 日, 140 日, 330 日のいずれの場合も, 深さ (0-8mm)，(11-19mm) では AER 混入モルタルの方が全 塩化物量は大きくなっている。

また，塩分含有モルタル側を見てみると，AERが混入 されている供試体と混入されていない供試体との比較で は，材齢 28 日，140日では全塩化物量の值の違いは僅か だが，材齢 330 日では，AER 混入モルタルを打ち継いだ 方が全塩化物量は明らかに減少している。このことは, AER を混入することによって, 既設モルタル中の塩分が AER 混入モルタル側に移動していることを示すもので, 塩分の拡散が生じていることが明らかとなった。

AER の有無と, 貼付けモルタル打ち継ぎ後の材齢 28 日と 330 日における全塩化物量の増減率について, 深さ (22-30mm) および（33-41mm）において求めたものを

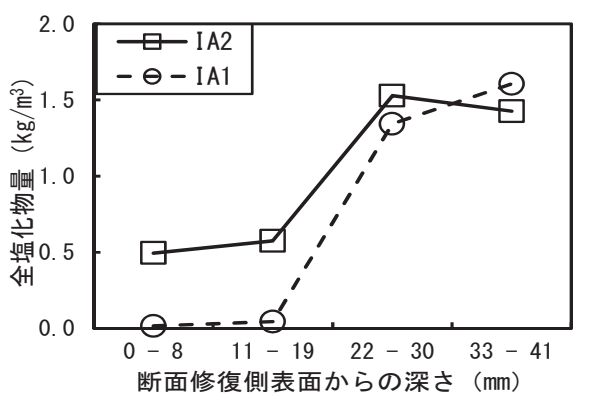

(a) 塩分含有量 $2 \mathrm{~kg} / \mathrm{m}^{3}$ （材齢 28 日）

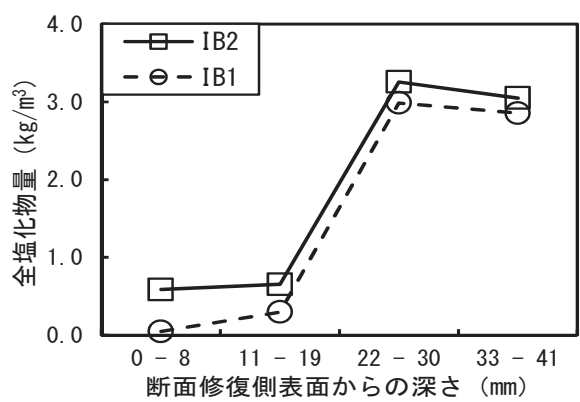

(d) 塩分含有量 $4 \mathrm{~kg} / \mathrm{m}^{3}$ （材齢 28 日）

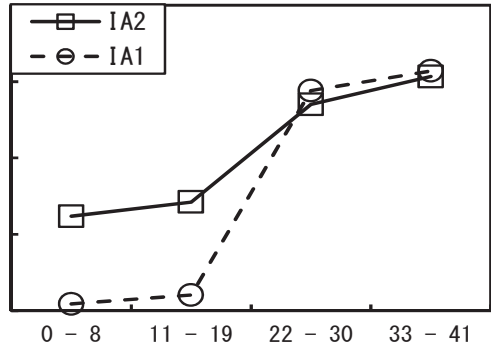

断面修復側表面からの深さ $(\mathrm{mm})$

(b) 塩分含有量 $2 \mathrm{~kg} / \mathrm{m}^{3}$ （材齢 140 日）

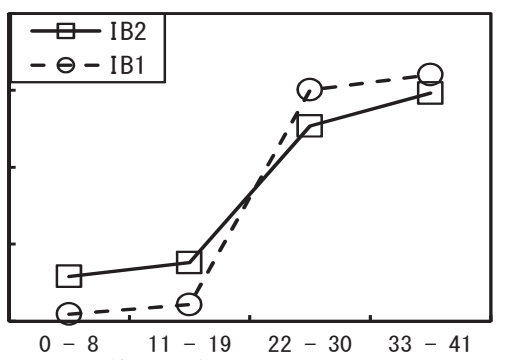

断面修復側表面からの深さ (mm)

(e) 塩分含有量 $4 \mathrm{~kg} / \mathrm{m}^{3}$ （材齢 140 日）

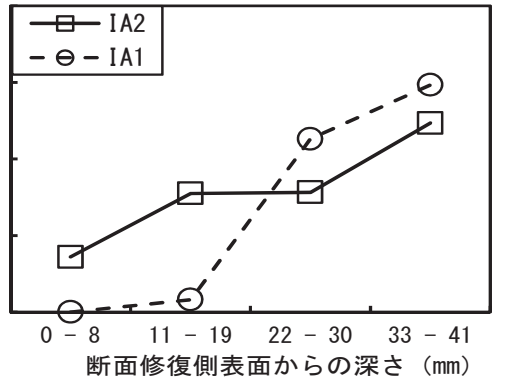

(c) 塩分含有量 $2 \mathrm{~kg} / \mathrm{m}^{3}$ （材齢 330 日）

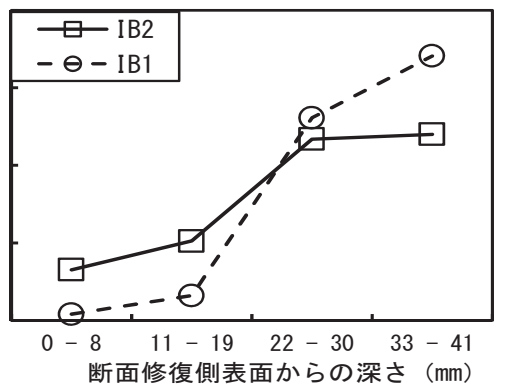

(f) 塩分含有量 $4 \mathrm{~kg} / \mathrm{m}^{3}$ （材齢 330 日）

図-14 断面修復側表面からの深さ位置と全塩化物量の関係 


\section{表一11 AER の有無と全塩化物量差の関係}

\begin{tabular}{|c|c|c|c|}
\hline \multirow{2}{*}{ 供試体 } & \multicolumn{3}{|c|}{ 全塩化物量の増加率 $(\%)$} \\
\cline { 2 - 4 } & $22-30 \mathrm{~mm}$ & $33-41 \mathrm{~mm}$ & 2 層平均 \\
\hline IA1 & -15.8 & -7.7 & -11.7 \\
\hline IA2 & -48.8 & -13.5 & -31.2 \\
\hline IB1 & -12.5 & 19.5 & 3.5 \\
\hline IB2 & -28.2 & -21.3 & -24.7 \\
\hline
\end{tabular}

表ー11 に示す。供試体 IA2 および IB2 は，各々が IA1 および IB1 よりも減少量が多く, AER 混入による塩化物 の拡散効果が明らかとなった。以上より, 塩害を受けた $\mathrm{RC}$ 構造物の表面部分に $\mathrm{AER}$ を混入した断面修復用モル タルを打ち込むことにより，コンクリート内部の塩分を 表面部方向に移動させ塩分を除去できる可能性が示され た。

\section{6. まとめ}

本研究は，イオン交換樹脂が持つ塩化物イオンの吸着 性能に着目し，化学的分析およびモルタル供試体を用い た塩分浸漬実験によるイオン交換樹脂の塩化物イオン吸 着効果, 補修向けモルタル中に混入させたイオン交換樹 脂による既設塩化物含有モルタル中の塩化物の減少効果 等を実験的に明らかにしたものである。本研究から得ら れた結論は以下に示すとおりである。

（1）ポルトランドセメントにイオン交換樹脂を混練し た場合，イオンの選択性により, セメント中の硫酸イオ ン $\left(\mathrm{SO}_{4}{ }^{2-}\right)$ がイオン交換樹脂に吸着されることが懸念され たが, セメントの練混ぜ水を用いた化学的分析試験結果 から，イオン交換樹脂が吸着できる全陰イオン量の約 $25 \%$ は硫酸イオンに占められるが, その他は塩化物イオ ンを吸着できることが明らかとなった。

（2）アルミナセメントを用いた場合には，硫酸イオン は含まないものの, アルミン酸イオン $\left(\mathrm{Al}(\mathrm{OH})_{4}^{-}\right)$が含 まれている。上記と同様な実験を行った結果, アルミン 酸イオンの選択性は塩化物イオンよりも小さく, 仮に初 期段階でアルミン酸イオン-がイオン交換樹脂に吸着さ れても, 塩化物イオンと置換されるため, 塩化物イオン の吸着性には問題がないことが明らかとなった。

（３）イオン交換樹脂を混入した早強セメントの凝結時 間は，コンクリート標準示方書が定める規格を満足し， イオン交換樹脂混入のモルタルの圧縮強度は, イオン交 換樹脂が混入されていないモルタルに比べて低くなるこ とが明らかとなった。

（4）イオン交換樹脂を混入したモルタルの塩分浸漬実 験を行い, 電位差滴定法および EPMAにより, 全塩化物 量を深さ方向に測定した。その結果，イオン交換樹脂を 混入することによって, より多くの塩化物イオンがモル タル中に浸透すること, イオン交換樹脂の混入率が増加
する程全塩化物量は増大することが明らかとなった。

（5）イオン交換樹脂を混入させたモルタルにおける塩 化物イオンの移動をシミュレーションすることを目的に, 固定塩化物を自由塩化物の関数としてモルタル中の自由 塩化物の拡散係数はモルタル中の深さ位置に依存しない という仮定，および，固定化塩化物はAERに吸着した塩 化物のみであるという仮定のもと, Langmuir 理論による 固定化係数を新たに算定した上で，フィックの拡散方程 式を一部修正して解析を行った。その結果，イオン交換 樹脂による塩化物イオン吸着現象をある程度の精度で説 明できることが明らかとなった。

（6）塩分 $(\mathrm{NaCl})$ を含有させたモルタルに，イオン交 換樹脂を混入したモルタルを貼り付けた供試体を作製し， 経時的に塩化物量を測定した。その結果，イオン交換樹 脂を混入することによって, 既設モルタル中の塩分が, イオン交換樹脂混入モルタル側に移動する現象が生じる ことが明らかとなった。このことは，塩害を受けた RC 構造物の表面部分にイオン交換樹脂を混入した断面修復 用モルタルを打ち込むことにより，コンクリート内部の 塩分を表面部方向に移動させ，塩分を除去できる可能性 を示唆するもので, 今後の適用性に道を開くものである。

謝辞: 本研究を行うにあたって，埼玉大学イノベーショ ンセンターの角田敦博士，株式会社デイ・シイの上平謙 二氏，二戸信和氏，オルガノ株式会社の山中弘次氏，中 橋知美氏，ケルネオスジャパンの Mr.Francois-Marie Albertini からは貴重かつ多くの専門的なご指導・ご助言 をいただいた。本研究は，科学技術振興機構（JST）の A-Step 探索タイプ (平成 23 年度) AS231Z04327C, 科学 研究費補助金（平成 24 年度萌芽研究代表 : 睦好宏史) により行われたものである。ここに記して感謝の意を表 す。

\section{参 考 文 献}

1）真田修・五藤正樹・䉓本武弘・柳澤博 : 塩害環境下の道路橋 $\mathrm{RC}$ 橋 脚補強における既設鉄筋の腐食塩分量算定手法の確立と塩害対策の 合理化施工, コンクリート工学年次論文集, Vol.31, No.1, pp.1021-1026, 2009

2）真田修・高木真由子・柳澤博・宒本武弘：西湘バイパス RC 橋脚而 震補強における塩害対策の合理化, コンクリート工学, Vol.48, No.2, pp.38-44, 2010

3) 藤井隆史・綾野克紀・阪田憲次 : イオン交換樹脂を用いたコンクリ 一下の脱塩効果に関寸る研究, 土木学会中国支部第 54 回研究発表会, V-17, pp.541-542, 2002

4) 敷地俊洋・睦好宏史・角田敦・杉原亮：イオン交換樹脂によるコン クリート中の塩化物イオン吸着効果に関寸る研究, 土木学会第 65 回 年次学術講演会, V-209, pp.417-418, 2010

5) 井上喜仁・真田修・睦好宏史：イオン交換樹脂を混入したモルタル の塩化物イオン吸着性, 土木学会第 66 回年次学術講演会, V-221, pp.441-442, 2011

6) JCI 規準集(1977〜2002 年度)「硬化コンクリート中に含まれる塩分の 
分析方法 (JCI-SC4)」, 日本コンクリート工学会, 2004.4

7) 真田修・M.P.C.M.Gunasekara・井上喜仁・睦好宏史 : イオン交換樹脂 による塩化物イオンの拡散抑制効果に関寸る実験的研究, コンクリ

一ト工学年次論文集, Vol.34, №.1, pp.742-747, 2012

8) コンクリート標準示方書規準編 JIS 規格集, 土木学会, pp.23, 2010

9) 図解コンクリート辞典, オーム社, pp.58-59, 2001

10) Martin-Perez B., Zibara H., Hooton R.D. and Thomas M.D.A.: A study of the effect of chloride binding on service life predictions, Cement and Concrete Research, 30, 2000, pp.1215-1223

11) 佐々木謙二・佐伯竜彦 : 混和材を用いたセメント硬化体における塩 化物イオン固定性状, コンクリート工学論文集, Vol.27, No.1, pp.691-696, 2005

12) 平尾宙 : セメントによる塩化物イオンの固定に関する研究, コンク リート工学, Vo.42, No.11, pp.55-61, 2004

注 : 既往の文献と本論文の供試体名の対応

本論 : IA1 $\Leftrightarrow$ 文献 7) : A1
本論 : IA2 $\Leftrightarrow$ 文献 7) : A2
本論 : IB1 $\Leftrightarrow$ 文献 7) : A3
本論 : IB2 $\Leftrightarrow$ 文献 7): A4

Characteristic of Chloride Ion Diffusion in Mortar Mixed with Ion-Exchange Resin

By Osamu Sanada, Hiroshi Mutsuyoshi, Shingo Asamoto and Nobuhito Inoue

Concrete Research and Technology, Vol.24, No.3, Sep. 2013

Synopsis: Recently, a number of concrete structures constructed several decades earlier are showing significant degradation, especially in coastal areas. For the effective repair and reinforcement of such structures, the development of high performance repairing material is required. Meanwhile, ion exchange resin has traditionally been used to remove impurities such as chloride in the process of cleaning industrial wastewater and manufacturing pure water. In this study, for the purpose of removing the chloride in deteriorated concrete structures, the application of ion exchange resin to repairing material is investigated. Firstly, the effect of ion exchange resin on the adsorption of chloride ion in mortar is examined by chemical analysis. The diffusion of chloride in mortar with ion exchange resin is experimentally and numerically studied. Finally, it is experimentally verified that the chloride in mortar is removed by inverse diffusion due to the ion exchange resin.

Keywords: Ion exchange resin, Chloride attack, Chemical analysis, Selectivity of ion, Immersion test in salt water, Diffusivity of chloride ion, Numerical analysis 